\title{
Budaya Organisasi Salah Satu Faktor Penentu Kinerja Karyawan
}

\section{Organizational Culture as a Kind of Factor Employee's Performance}

\author{
Marlina Deliana \\ Administrasi Publik, Fakultas Ilmu Sosial dan Ilmu Politik, Universitas medan Area, Indonesia
}

Diterima: 23 September 2020; Direview: 26 September 2020; Disetujui: 17 Oktober 2020

*Coresponding Email: deliana433@gmail.com

\begin{abstract}
Abstrak
Budaya organisasi menjadi salah satu faktor pendorong yang membedakan hasil kinerja dari suatu perusahaan. Budaya organisasi diusulkan kepada karyawan sebagai cara suatu pekerjaan dilakukan. Budaya nasioal dan sosial masyarakat dari suatu negara mempengaruhi budaya organisasi, berdasarkan model Hofstede dan Trompeneaar terdapat dimensi ukuran dari budaya masyarakat yang mempengaruhi dan membentuk nilai dan norma seseorang pendiri, karyawwan, dan pelanggan dari suautu perusahaan. Kinerja adalah hasil dari kemampuan karyawan ditambah dengan effort dan support. Kemampuan dari seseorang berpengaruh dipengaru oleh bakat dan ketertarikan, sementara effort dipengaruhi oleh motivasi, insentif dan pola kerja. Pentingnya budaya organisasi terhadap kinerja karyawan memiliki dua pandangan penelitian. Sebagian peneliti menganggap bahwa budaya organisasi tidak secara signifikan berpengaruh terhadap kinerja, sedangkan sebagian penelitian membuktikan bahwa budaya organisasi memiliki pengaruh yang positif dan signifikan terhadap kinerja karyawan. Budaya organisasi yang banyak ditemukan Indonesia budaya organisasi adalah budaya hirarki, yaitu berfokus pada kontrol dan stabilitas berhubungan dengan sistem birokrasi. Sehingga hal ini menjadi salah satu faktor, dimana budaya organisasi bukanlah faktor penentu dari peningkatan kinerja.
\end{abstract}

Kata Kunci: Budaya Organisasi, Kinerja Karyawan

\begin{abstract}
Organizational culture is one of the factors that differentiate the performance results of a company. Organizational culture is proposed to employees as the way a job is done. National and social culture of a country influences organizational culture, based on the Hofstede's and Trompeneaar's model, there are dimensions of community culture that influence and shape the values and norms of a founder, employees, and customers of a company. Performance is the result of an employee's ability coupled with effort and support. The ability of an influential person is influenced by talent and interest, while effort is influenced by motivation, incentives and work patterns. The importance of organizational culture on employee performance has two research views. Some researchers consider that organizational culture has no significant effect on performance, while some studies prove that organizational culture has a positive and significant effect on employee performance. Organizational culture that is found in many Indonesians organizational culture is a hierarchical culture, which focuses on control and stability associated with the bureaucratic system. So that this becomes one of the factors, where organizational culture is not a determining factor for improving performance.
\end{abstract}

Keywords: Organizational culture, Employee Performance

How to Cite: Deliana, M. (2020). Budaya Organisasi Salah Satu Faktor Penentu Kinerja Karyawan. Journal of Education, Humaniora and Social Sciences (JEHSS). 3 (2): 518-523. 


\section{PENDAHULUAN}

Budaya organisasi menjadi salah satu faktor pendorong yang membedakan hasil kinerja dari suatu perusahaan. Budaya organisasi diusulkan kepada karyawan sebagai cara suatu pekerjaan dilakukan. Sebagai contoh perusahaan Jepang, memiliki prinsip budaya yang tumbuh dan berkenbang dengan menerapkan nilai-nilai budaya masyarakat yang kemudian di terapkan dalam organisasi untuk menjadi budaya organisasi. Filosofi jepang yang paling utama yang dimiliki oleh setiap perusahaan jepang adalah sikap loyal dan pekerja keras. Hal ini terlihat dari sangat jarang karyaan jepang yang berpindah-pindah tempat pekerjaan, ini diakibatkan karena perusahaan sangat menghargai sumber daya yang dimiliknya sehingga karyawan di anggap sebagai investasi masa depan yang akan terus dijaga dengan membrikan pelatihan dan pengembangan sesuai dengan bidang keahliannya. Jepang memiliki jam kerja rata-rata 2450 jam/tahun dan kebanyakan karyawan akan pulang lebih lama dari jam kantor karena hal itu menandakan bahwa karyawan tersebut sangat dibutuhkan. Berbeda dengan di Indonesia yang mterkenal dengan sifat santai hal ini juga sedikit banyak terbawa dalam menyelesaikan pekerjaan. Hal ini terlihat dari beberapa karyawan untuk melakukan lembur kerja itu sangat jarang, apalagi jika organisasi itu adalah organisasi publik. Karyawan cenderung pulang sesuai dengan jam kantor atau bahkan lebih cepat dari jam kantor yang telah ditetapkan

Hostede (2011) menyebut budaya nasioal dan sosial masyarakat dari suatu negara mempengaruhi budaya organisasi, berdasarkan model Hofstede dan Trompeneaar terdapat dimensi ukuran dari budaya masyarakat yang mempengaruhi dan membentuk nilai dan norma seseorang pendiri, karyawwan, dan pelanggan dari suautu perusahaan dalam (Hofstede, 2011; Maamari \& Saheb, 2018). Phiti Sithi Amnuai mengemukakan budaya organisasi adalah seperangkat asumsi dasar dan keyakinan yang dianut anggota-angggota, kemudian dikembangkan dan diwariskan yang diadopsi dari ekternal dan intgerasi internal sebagai dasar dalam mengatasi permasalahan (Pabundu, 2006). Biasanya budaya yang dimiliki perusahaan menjadi pembeda diantara organisasi-organisasi lain. Budaya organisasi juga merupakan sistem nilai yang diadopsi oleh karyawan untuk dapat mencapai tujuan organisasi. Budaya organisasi merupakan seperangkat nilai, kepercayaan, dan cara karyawan melakukan sesuatu dalam organisasi. Sebagaimana disebut oleh Hal ini berarti bagaiamana karyawan tersebut bekerja dan berprilaku untuk menyelesaikan tugasnya dan bagaimana kepedulian terhadap apa yang muncul dalam lingkungan organisasinya ((Mgbere, 2009; Hofstede, 2011; Maamari \& Saheb, 2018).

Manifestasi dari budaya organisasi terlihat dan terdengar; artifak seperti alat, gedung, seni, dan teknologi juga bentuk dari perilaku manusia termasuk kemampuan berbicara. Walaupun manifestasi itu terlihat, mereka hanyalah sebuah simbol budaya itu sendiri yang sebenanrya tidak terlihat dan dimana bahkan tidak diperdulikan oleh orang-orang. Dari manifestasi budaya inilah lahir nilai dari organisasi, biasanya tertulis dalam bentuk kode bahasa (Owens \& Steinhoff, 1989). Pada dasarnya, ada tiga macam proses terbentuknya budaya organisasi, yaitu: proses pertama adalah budaya memang diciptakan oleh pendirinya, proses kedua, budaya terbentuk sebagai upaya menjawab tantangan dan peluang dari lingkungan internal dan eksternal, proses ketiga, adalah budaya diciptakan oleh tim manajemen sebagai cara untuk meningkatkan kinerja organisasi secara sistematis (Moeljono \& Sudjatmiko, 2007). Schein menyatakan secara teoritis proses pembentukan budaya oranisasi dapat dianalisis dari tia teori yaitu: Teori sociodynamic, teori kepemimpinan, dan teori pembelajaran. Teori sociodynamic menekankan pada kelompok yang mempunyai program interpersonal dan emosional. Teori kepemimpinan, teori ini menaknkan hubungan antara pemimpin dengan kelompok dan efek personalitas dan gaya kepemimpinan terhadap formasi kelompok yang sangat relevan dengan pengertian bagaimana budaya terbentuk. Teori pembelajaran, memberikan bagaimana kelompok mempelajari kognitif, perasaan dan penilaian (Pabundu, 2006).

Menurut Bateman (2007) terdapat empat jenis budaya organisasi, yaitu: Budaya kelompok, budaya hirarkis, budaya rasional, dan adokrasi. Budaya kelompok berorientasi internal dan fleksibel, budaya ini cenderung di dasarkan pada nilai-nilai dan norma yang dikaitkan dengan pertalian, Kepercayaan, tradisi, dan komitmen jangka panjang merupakan kepatuhan anggota 
dari arahan organisasi. Budaya hirarkis, lebih ditekankan pada kontrol dan stabilitas. Memiliki nilai dan norma yang berhubungan dengan sistem birokrasi. Budaya ini cenderung banyak ditemukan padaa organisasi publik pemerintahan. Budaya rasional, berorientasi eksternal dan fokus pada kontrol. Sasaran utama adalah produktivitas, perencanaa, dan efisiensi. Menekankan pada imbalan sebagai motivasi dalam pencapaian sasaran-sasaran organisasi. Adokrasi adalah budaya yang berorientasi eksternal dan fleksibel. Menekankan perubahan yang didalamnya pertumbuhan, akuisis sumber daya, dan inovasi sangat di dukung (Bateman, 2007). (Robbins \& Judge, 2013) menunjukkan bahwa organisasi dua tipe budaya, disebut: budaya dominan yaitu budaya yang merepresentasikan bahwa nilai dianut oleh sebagian besar anggotanya dan membuat organisasi memiliki ciri khas, kemudian yang kedua disebut sub-culture, budaya yang muncul dari perbedaan departemen/unit dan area geografi yang berbeda (Pawirosumarto, Sarjana, \& Gunawan, 2017).

Kinerja di suatu organisasi dilakukan oleh segenap sumber daya manusia dalam organisasi, baik unsur pimpinan maupun pekerja. Menurut Armstrong dan Baron (1998) dalam widodo (2007) menyebut "kinerja merupakan hasil pekerjaan yang mempunyai hubungan kuat dengan tujuan strategis organisasi, kepuasan konsumen, dan memberikan kontribusi pada ekonomi.Dengan demikian, kinerja adalah tentang melakukan pekerjaan dan hasil yang dicapai dari pekerjaan tersebut" (Widodo, 2007). Kinerja karyawan adalah hasil secara kualitas dan kuantitas yang dicapai oleh karyawan dalam melaksanakan tugasnya sesuai dengan tanggung jaab yang diberikan (Mangkunegara, 2006). Armstrong dan Baron dalam (Widodo, 2007) terdapat 5 (lima) faktor yang mmpengaruhi kinerja antara lain: Personal Factors (tingkat keterampilan), Leadership factor (kualitas dan dorongan pemimpin), Team factor (kulitas dukungan kelompok), System factor (sistem kerja/budaya dan fasilitas yang disediakan), contextual/situational factor (tekanan dari lingkungan).

Kinerja adalah hasil dari kemampuan karyawan ditambah dengan effort dan support. Kemampuan dari seseorang berpengaruh dipengaru oleh bakat dan ketertarikan, sementara effort dipengaruhi oleh motivasi, insentif dan pola kerja. Dukungan dari organisasi termasuk pelatihan pengembangan sumber daya manusia dan ketersediaan kemampuan peralatan organisasi (Gordon, 2000; Pawirosumarto, Sarjana, \& Gunawan, 2017). Terkadang terminologi kinerja disamakan dengan produktivitas padahal menurut Ricardo dan Wade (2011) dalam (Shahzad, 2014) menyatakan bahwa kinerja dan produktivitas adalah dua hal yang berbeda. Produktivitas berarti ratio yang merepresentasikan volume kerja yang telah dilakukan selama periode tertentu, sementara kinerja adalah indikator produktivitas, konsistensi, dan kualitas dari pekerjaan. Budaya dan kinerja dianggap saling terkait satu dengan yang lain oleh manajemen yang kuat. Budaya organisasi membantu menginternalisasi hubungan yang mengarah pada pengelolaan proses organisasi yang efektif. Produktivitas dan budaya organisasi membantu meningkatkan kinerja (Awadh \& Saad, 2013). Pentingnya budaya organisasi terhadap kinerja karyawan memiliki dua pandangan penelitian. Sebagian peneliti menganggap bahwa budaya organisasi tidak secara signifikan berpengaruh terhadap kinerja, sedangkan sebagian penelitian membuktikan bahwa budaya organisasi memiliki pengaruh yang positif dan signifikan terhadap kinerja karyawan.

\section{PEMBAHASAN}

Banyak peneliti percaya bahwa terdapat hubungan antara budaya organisasi dengan kinerja karyawan. Kinerja perusahaan sangat bergantung pada budaya organiasi, faktanya bahwa sikap adalah bagian dari budaya organisasi dan bagian dari kinerja karyawan akan meluruskan hubungan antara budaya organisasi dan kinerja. Hubungan antara kepercayaan, partisipasi, dan kinerja dikaitkan oleh budaya organisasi (Maamari \& Saheb, 2018). Pembahasan mengenai budaya organisasi dalam kaitannya dengan kinerja sangat luas. Hal ini disebabkan nilai-nilai budaya organisasi dapat diterjemahkan sebagai filosofi usaha, asumsi dasar, moto organiasi, misi/tujuan umum organisasi, serta prinsip-prinsip yang menjelaskan usaha (Pabundu, 2006). Menurut Pabundu (2006) logika tentang budaya berhubungan dengan kinerja meliputi: penyatuan tujuan, budaya kuat membantu kinerja organisasi karena menciptakan tingkat 
motivasi dalam diri karyawan, memberikan struktur dan kontrol yang dibutuhkan. Budaya yang kuat dalam organisasi sangat membantu untuk meningkatkan kinerja karyawan (Shahzad, 2014). Budaya organisasi yang kuat di organisasi meningkatkan komitmen karyawan dalam mencapai tujuan organisasi. Hal ini sangat membantu untuk meningkatkan kinerja karyawan. Kepercayaan individu berbeda dari nilai organisasi ketika seorang karyawan masuk dalam organisasi (Shahzad, 2014). (Kozlowski \& Klein, 2000) melaporkan bahwa organisasi secara sadar mengkoordinasikan sistem dimana karakterisitik dari indiividu, group, dan organisasi saling berinteraksi, dan dimana interaksi yang efektif diantara mereka secara kuat tergantung pada budaya organisasi yang membentuk kinerja individu pada banyak kasus (Maamari \& Saheb, 2018).

Perdana (2012) menyatakan bahwa Budaya kerja mempengaruhi kinerja karyawan dengan faktor kedisiplinan merupakan faktor budaya yang paling dominan dalam meningaktkan kinerja (Perdana, 2012). Budaya organisasi yang kuat dicirikan oleh gaya kepemimpinan yang spesifik akan berdampak pada kinerja banyak orang (Maamari \& Saheb, 2018). Penelitian yang dilakukan oleh Shahzad (2014) menyatakan bahwa terdapat hubungan yang positif antara budaya perusahaan dengan kinerja karyawan di Software House Pakistan. Budaya organisasi yang kuat meningkatkan komitmen karyawan terhadap pencapaian tujuan organisasi (Shahzad, 2014). Jika merujuk pada teori yang telah dipaparkan sebelumnya terbukti bahwa penelitian yang telah dilakukan oleh beberapa peneliti sebelumnya membukatikan budaya organisasi memiliki pengaruh terhadap kinerja karyawan.

Namun hal berbeda dihasilkan oleh beberapa peneliti yang mengaangap bahwa budaya organisasi tidak sepenuhnya mempengaruhi kinerja. Seperti yang dilakukan oleh Anugrah (2010) menyatakan bahwa budaya perusahaan memiliki hubungan yang sangat kuat dan signifikan terhadap kinerja karyawan (Anugrah, 2010). Penelitian yang dilakukan pada PT. Bank Sumsel oleh Delamat (2002), menyatakan bahwa PT.Bank Sumsel berusaha menumbuhkan budaya organisasi dalam upaya meningkatkan kinerja perusahaan. Pada penelitian ini korelasi antara Budaya organisasi dengan kinerja karyawan sangat lemah (Delamat, 2002). Budaya organisasi adalah sistem nilai atau symbol yang dimengerti, dipercaya, dan melekat bersama sebagai sistem perekat dan membedakan organisasi satu dengan yang lainnya. Penelitian pada Parador Hotel dan Resort menunjukkan bahwa budaya organisasi tidak secara signifikan mempengaruhi kinerja karyawan, dimana budaya organisasi di Prada Hotel dan Resort berfungsi sebagai pengetahuan sosial, identitas,dan perilaku karyawan (Pawirosumarto, Sarjana, \& Gunawan, 2017).

Berdasarkan dari pemaparan tinjauan teori dan literatur, masih menjadi perdebatan apakah budaya organisasi dapat menjadi faktor penentu dalam kinerja karyawan atau tidak. Terlihat dari beberapa penelitian yang telah dilakukan masih terdapat perbedaan hasil dari pengaruh budaya terhadap kinerja karyawan. Berdasarkan dari tinjauan literature yang telah dikemukakan, budaya organisasi terbentuk dari budaya masyarakat yang kemudian di adopsi oleh perusahaan untuk menjadi dasar dalam membentuk budaya organsisasinya. Hal ini mungkin berlaku di organisasi pada beberapa Negara. Seperti Jepang, China, Amerika dan sebagainya yang memiliki budaya disiplin yang tinggi, dan pekerja keras. Kebanyakan organisasi terutama organisas Jepang mengadopsi budaya yang berkembang di masyarakat sebagai budaya organisasinya. Dengan budaya pekerja keras dan budaya malu yang tinggi seorang karyawan tidak akan pulang jika pekerjaannya belum selesai. Budaya organisasi yang banyak terbentuk pada organisasi/perusahaaln luar negeri lebih cenderung pada budaya kelompok dan budaya rasional. Dimana budaya kelompok merupakan budaya yang didasarkan pada norma dan nilai yang dikaitkan. Sedangkan budaya rasional berfokus pada produktivitas, perencanaan, dan efisiensi.

Budaya organisasi yang banyak ditemukan Indonesia budaya organisasi adalah budaya hirarki, yaitu berfokus pada kontrol dan stabilitas berhubungan dengan sistem birokrasi. Sehingga hal ini menjadi salah satu faktor, dimana budaya organisasi bukanlah faktor penentu dari peningkatan kinerja. Terbukti dari beberapa hasil penelitian yang dilakukan bahwa budaya 
organisasi tidak menunjukkan adanya pengaruh yang signifikan terhadap kinerja karyawan. JIkapun terdapat hasil yang berbeda dipastikan bahwa terdapat faktor penghubung lain yang mengakibatkan budaya organisasi berpengaruh terhadap kinerja karyawan. Seperti contohnya pengaruh gaya kepemimpinan, kinerja karyawan di Indonesia cenderung dilihat bagaimana gaya seseorang dalam memimpin suatu organisasi. Budaya organisasi di Indonesia lebih kepada identitas. Hal ini terbukti dari penelitian yang dilakukan pada Prada Hotel dan Resort, dimana dinyatakan bahwa budaya organisasi hanya beruna sebagai identitas, dan pengetahuan sosial bagi karyawannya. Hal ini juga mungkin dipengaruhi oleh banyaknya budaya yang ada di Indonesia. Setiap daerah memiliki budayanya sendiri-sendiri. Sangat sulit untuk menentukan dan menyama ratakan budaya organisasi di setiap daerah. Karena pada dasarnya setiap daerah memiliki sistem nilai dan budayanya sendiri-sendiri. Inilah yang menjadi faktor kenapa kinerja karyawan lebih ditentukan pada gaya kepemimpinan daripada budaya organisasi.

\section{SIMPULAN}

Budaya organisasi tidak selamanya memiliki pengruh terhadap kinerja karyawan. Hal ini terbukti dari beberapa penelitian yang membuktikan bahwa budaya tidak berpengaruh signifikan terhadap kinerja karyawan. Namun di beberapa organisasi luar negeri, peran budaya sangat penting bagi peningkatan kinerja karyawan. Budaya organisasi pada perusahaan luar negeri seperti contohnya Jepang sangat mempengaruhi kinerja karyawan dengan budaya kerja kerasnya. Sedangkan di Indonesia Budaya organisasi yang banyak ditemukan adalah budaya hirarki, yaitu berfokus pada kontrol dan stabilitas berhubungan dengan sistem birokrasi. Sehingga hal ini menjadi salah satu faktor, dimana budaya organisasi bukanlah faktor penentu dari peningkatan kinerja. Perlu adanya penelitian lebih lanjut untuk membuktikan apakah budaya organisasi memiliki pengaruh pada kinerja karyawan. Dengan mempertimbangkan beberapa faktor mediator seperti gaya kepemimpinan, demografi, jenis kelamin, atau faktor lain yang mungkin mempengaruhi budaya organisasi terhadap kinerja karyawan.

\section{DAFTAR PUSTAKA}

Anugrah, W. P. (2010). Pengaruh Budaya Perusahaan Terhadap Kinerja Karyawan (Studi korelasi di PT. Karakatau Industrial Estate Cilegon). Serang: Fakultas ILmu Sosial dan Ilmu POlitik Universitas Ageng Tirtayasa.

Awadh, A. M., \& Saad, A. M. (2013). Impact of Organizational Culture on Employee Performance. Internaational Review of Management and Business Reaserch, 2(1), 168-175.

Bateman, S. (2007). Manajemen. Jakarta: Salemba Empat.

Delamat, N. (2002). Pengaruh Budaya Perusahaan Terhadap Kinerja Karyawan Bank Sumsel. Palembang: Universitas Sriwijaya.

Gordon, J. (2000). Organisasi, Prilaku Struktur, Proses edisi 8. Jakarta: Bina Rupa Aksara.

Hofstede, G. (2011). DImesionalising Cultures : The Hofstede Model in Context. Online Reading in Psychological and Culture, 1-26.

Kozlowski, S., \& Klein, K. (2000). A Multilevel Aproach to Thepry Research in Organizations: Contextual, Temporal, and Emergent Process. In K.J. Klein \& S.W.J Kozlowski (Eds). San Fransisco: CA: Jossey-Bass.

Maamari, B. E., \& Saheb, A. (2018). How Organizational Culture and Leadership Style Affect Employee's Performance of Genders. International Journal of Organizational Analysis, 124.

Mangkunegara, P. (2006). Evaluasi Kinerja SDM. Bandung: Refika Aditama. 
Mgbere, O. (2009). Exploring the Relationship between Organizational culture, Leadership Style And Coorporate Performance: An Overreview . Journal of Strategic Management Education, 187-201.

Moeljono, D., \& Sudjatmiko. (2007). Corporate Culture Challange to Exccelent. Jakarta: Gramedia.

Owens, R., \& Steinhoff, C. (1989). Toward a Theory of Organizational Culture. Journal of Educational Administration, 27(33), 6-16.

Pabundu, H. T. (2006). Budaya Organisasi dan Peningkatan Kinerja Perusahaan. Jakarta: Bumi Aksara.

Pawirosumarto, S., Sarjana, P. K., \& Gunawan, R. (2017). the Effect of Work Environment, leadership style, and organizational culture towards job satisfaction and Its Implication Toward Employee Performancein Paraador Hotels and Resort, Indonesia. International Journal of Law and Management, 59(6), 1337-1358. doi:https://doi.org/10.1108/IJLMA10-2016-0085

Perdana, R. R. (2012). Pengaruh Budaya Kerja terhadap Kinerja karyawan di KOPERASI Karyawan Redrying Bojonegoro (KAREB). Malang: Fakultas Pertanian, Jurusan Sosial Ekonomi Pertanian, Universitas Brawijaya.

Robbins, S., \& Judge, T. (2013). Organizational Behavior 15th Edition. Boston,MA: Pearson Education.

Shahzad, F. (2014). IMpact of Organizational culture on Employees' Job Performance: An Empirical Study of Softwere Houses In Pakistan. International Journal Of Commarce Management, 24(3), 219-227. doi: https://doi.org/10.1108/IJCoMA-07-2012-0046

widodo. (2007). Manajemen Kinerja. Jakarta: Raja Grafindo Persada. 